\title{
UVODNIK
}

\section{IZOBRAŽEVANJE ODRASLIH NA PODROČJU ZDRAVIA: POMEN DRUŽBENOKULTURNIH DIMENZIJ IN INTERDISCIPLINARNOSTI}

Izobraževanje odraslih na področju zdravja postaja vedno bolj obsežno polje v andragogiki ter drugih družboslovnih, humanističnih in medicinskih vedah (English, 2012; Nutbeam, 2019; Wang, 2014), kar se med drugim odraža v samostojnih revijah (npr. Health Education Journal), interdisciplinarno zasnovanih razpravah o raziskovanju, kot npr. v Social Theory and Health Education (Leahy idr., 2020), v mednarodnih projektih (npr. Last Aid), mnogovrstnosti praks in tudi v pestrosti poimenovanj: zdravstvena vzgoja, izobraževanje za zdravje, zdravstveno izobraževanje, vzgoja in izobraževanje za zdravje, razvoj zdravstvene pismenosti ali zdravstveno opismenjevanje, ozaveščanje o zdravju.

Temeljni namen vseh teh dejavnosti je razvoj zmožnosti, da ljudje ohranjajo zdravje in se ob težavah z zdravjem informirano odločajo. S tem mislimo na razvoj zmožnosti pri različnih skupinah (mlajši odrasli, starejši odrasli, splošna javnost), da pridobivajo, razumejo in uporabijo informacije, pomembne za odločanje in ravnanje, povezano z zdravjem (Nutbeam idr., 2019, str. 1). Z besedno zvezo vzgoja in izobraževanje za zdravje poimenujemo vse procese oblikovanja/vzgajanja in spodbujanja človeka-v-okolju z namenom, da razvija zmožnosti emocionalnega, kognitivnega in somatskega učenja ter ravnanja z zdravjem ali boleznijo. Vzgoja in izobraževanje za zdravje je holističen proces, vključuje celotno osebo in njeno okolje. To torej ni proces, ki bi bil ločen od okolja. Sodobne teoretske paradigme in praktične aktivnosti so osredotočene na to, da vzgoja in izobraževanje kot proces in kot dejavnost, ki naj prispevata k zdravju ljudi ali uravnavanju bolezni, izhajata iz družbenokulturnih okoliščin. To pomeni, da morajo izobraževalci poznati širši družbenokulturni kontekst, politične in ekonomske značilnosti posameznega okolja in tudi njegove biološke ter okoljske razsežnosti. Poleg makroelementov morajo tako poznati tudi tradicijo, znanje, navade tiste skupine, za katero pripravljajo izobraževalne programe, ter značilnosti posameznika (Gilbert idr., 2015; Leahy idr., 2020; Willis idr., 2014). Ker so vsi ti makro- in mikroelementi, odnosi in procesi del družbenokulturnega sistema, je treba o njih tudi kritično misliti. To implicira, da se zavedamo različnega razumevanja pojmov zdravje, bolezen in zdravljenje, na kar opozarjajo medicinski antropologi.

Doživljanje in razumevanje zdravja je torej odvisno od družbenokulturnega okolja. Prav tako pa je odvisno od teoretskih interpretativnih vzorcev. Za interpretativno ogrodje se 
vedno pogosteje uporabljajo integrativni bio-psiho-socialni modeli, med katere uvrščamo model salutogeneze, ki v ospredje postavlja procese spodbujanja zdravja. To velja tudi za takšne situacije, ki so povezane s kroničnimi boleznimi, travmami, primanjkljaji, ovirami. V razpravah srečamo tudi koncepte, kot sta trdoživost (resilience) in blagostanje (well-being).

Vzgoja in izobraževanje za zdravje sta namenjena različnim ciljnim skupinam: tako tistim, ki imajo težave z zdravjem, kot tistim, ki naj bi se izognile težavam na tem področju. Poseben izziv so programi za izobraževanje posebnih ciljnih skupin, kot so manjšine, migranti, starejši, ter posebne tematike, npr. izobraževanje za higieno ustne votline, promocija zgodnjega odkrivanja in zdravljenja raka dojk, detabuizacija težav v duševnem zdravju, ozaveščanje o rabi kontracepcije, izobraževanje pri pripravi na porod in druge vrste izobraževanja staršev (gl. Lauzon in Farabakhsh, 2014; Silberberg, 2020). S sodobnimi demografskimi spremembami, kot so migracije, se odpirajo še dodatne tematike, npr. vprašanja o izobraževanju za sporazumevanje, vprašanja o večkulturnih stikih s tujejezičnimi bolniki v zdravstvenih ustanovah (gl. Pokorn in Lipovec Čebron, 2019).

Izobraževanje za zdravje je v svojem razvoju prešlo različne faze. Najprej je bilo namenjeno predvsem preventivnim programom, s katerimi so se ljudje opolnomočili za odločanje in ravnanje pri ohranjanju zdravja (npr. spoštovanje pravil higiene, skrb za doječe matere in novorojenčke), pozneje pa se je razvilo v izobraževanje za zdravje, ki je zasnovano $\mathrm{z}$ namenom formiranja ali transformiranja navad in praks $\mathrm{v}$ vsakdanjem življenju (npr. zdrava prehrana in gibanje). Poleg preventivnih programov se razvijajo tudi programi, ki so namenjeni spoprijemanju z boleznijo ter razvoju novih veščin in navad (npr. razvoj prehranskih navad pri diabetesu). Naslednja značilnost v razvoju izobraževanja za zdravje je povezovanje različnih akterjev pri pripravi programov. Povezujejo se izobraževalni in zdravstveni sistem, sistemi politike in upravljanja, sistem dela. Nosilci izobraževanja, učenja in promoviranja so različni. Prav tako so zelo raznolike strategije izobraževanja, ki se približujejo skupnostnemu izobraževanju in načelom skupnostne psihologije (Francescato idr., 2020; Seedat idr., 2017).

Ob vsem tem se zastavlja tudi vprašanje raziskovalnih strategij. Raziskave so v preteklosti slonele predvsem na pozitivistični paradigmi, v sodobnosti pa se porajajo novi kvalitativni in postkvalitativni pristopi (Cardano idr., 2020). Sprašujemo se, kako v raziskovanju in razvoju izobraževanja odraslih na področju zdravja odsevajo t. i. obrati: narativni obrat, afektivni obrat. Kakšna je uporaba avtoetnografije, biografske metode, narativnih metod? Kakšna je vloga akcijskega raziskovanja in participatornega akcijskega raziskovanja glede na poststrukturalistično teorijo prakse? Kako na raziskovanje in razvoj vzgojno-izobraževalnih programov za zdravje vplivajo »neoliberalni časi« in težnje po komodifikaciji zdravja, izobraževanja? Kako na izobraževanje za zdravje vplivajo pritiski, da bi »šibkosti« nekaterih ljudi in skupin razumeli kot nekaj samoumevnega in odvisnega zgolj od njih samih? Če sprejmemo ugotovitve, da je znanje družbenokulturno umeščeno, kakšne so epistemološke, didaktične, etične posledice in implikacije za načrtovanje raziskav in izobraževalnih programov? Ali raziskovalne strategije dajejo glas vsem vključenim v 
vzgojo in izobraževanje za zdravje? Kako na izobraževalne programe vplivajo intersekcijske neenakosti in ali jih $\mathrm{v}$ raziskavah zaznamo?

Družbenokulturni, politični in ekonomski vidiki so zelo pomembni za razumevanje odzivanja prebivalcev na bolezni, okužbe, epidemije ter za analiziranje ukrepov, na katere se skupine ljudi različno odzivajo. Nekatere skupine v času epidemije covida-19, ki povzroča velike kognitivne disonance in negotovosti, iščejo referenčne točke, ki bi pomagale pri urejanju kaotičnosti, tudi tako, da se zatečejo v popačeno interpretacijo znanstvenih spoznanj. Vsi ti izzivi implicirajo razmislek o razmerjih med zdravjem in znanjem, spretnostmi, navadami, učenjem, epistemološkimi sistemi ipd. Razmisliti je treba o temah, kot so: družbenokulturni vidiki zdravja, bolezni in zdravljenja, vloga skupnosti v izobraževanju odraslih za zdravje ter vloga skupnostnega učenja in izobraževanja pri spoprijemanju z zdravstvenimi težavami.

$\mathrm{V}$ tej tematski številki je odnos med izobraževanjem in zdravjem/boleznijo osvetljen $z$ dveh zornih kotov. Prvi obravnava vpliv izobraževanja, vključenosti v izobraževalne programe na zdravje in dobro počutje. Vključenost mlajših odraslih in starejših odraslih v izobraževanje vpliva na dobro počutje in zdravje. Izobraževanje, ki ga izvajajo na švedskih ljudskih univerzah in je namenjeno ljudem $\mathrm{z}$ avtizmom, prispeva $\mathrm{k}$ rehabilitaciji in predstavlja podporno okolje. Hedegaard, Hugo in Bjursell v članku Ljudska univerza kot spodbudno okolje za udeležence z visoko funkcionalnim avtizmom ugotavljajo, da je izobraževanje za udeležence $\mathrm{z}$ avtizmom pozitivno $\mathrm{z}$ vidika udeležencev, zaposlenih in ravnateljev. Meulenberg v prispevku Dvojezičnost in jezikovno izobraževanje za izboljšanje kognitivnega zdravja starejših ljudi analizira vpliv dvojezičnosti in implikacije za jezikovno izobraževanje starejših, saj lahko k zdravemu staranju pripomore tudi aktivna raba več jezikov. Formosa v svojem članku Zbiranje dokazov o vplivu učenja starejših odraslih na aktivno staranje: kvantitativna študija pa predstavlja rezultate študije o tem, da ima učenje starejših močan pozitiven vpliv na dejavno staranje, saj učenje blaži socialno izolacijo in kognitivno slabitev. Izobraževanje v starosti prispeva k boljšemu zdravju, telesnemu in duševnemu blagostanju.

Drugi zorni kot razmerja med zdravjem in izobraževanjem odpira pogled na izobraževanje, ki je ciljno pripravljeno z namenom izboljševanja znanja o zdravju/bolezni. Prosen in Ličen v članku Izboljševanje zdravstvene pismenosti nosečnic z uporabo sodobnih pristopov v zdravstveni vzgoji: integrativni pregled literature razčlenita koncept zdravstvene pismenosti kot ključne socialne determinante zdravja ter razmišljata o sodobnih pristopih zdravstvene vzgoje za nosečnice v t. i. razvitem svetu. Ugotavljata, da je proces posodabljanja zdravstvene vzgoje prepočasen in premalo progresiven. Podobno ugotavlja tudi Švab o vlogi splošnih knjižnic, ki bi lahko bile zelo pomembni akterji pri ozaveščanju javnosti o zdravju in tudi o lažnih novicah, ki so z njim povezane. Avtorica članka Zdravstveni kotički in izobraževanje za zdravje v splošnih knjižnicah je v svoji raziskavi analizirala prednosti in pomanjkljivosti delovanja zdravstvenih kotičkov v slovenskih splošnih knjižnicah. Zapiše, da so poseben izziv pri načrtovanju in izvajanju izobraževanja za zdravje informacijsko slabše pismeni prebivalci, zato bi morali zdravstveni kotički razviti 
nove strategije delovanja, ki bi se približale različnim ciljnim skupinam. Posebno področje za načrtovanje izobraževalnih programov so teme, ki so v našem kulturnem okolju še vedno tabuizirane. Taka tema je umiranje. Zelko, Jakšič in Krčevski Škvarč v svojem članku Ozaveščanje javnosti o paliativni oskrbi: evalvacija tečaja Zadnja pomoč (Last Aid) v Sloveniji opisujejo izkušnje iz mednarodnega projekta skupnostnega izobraževanja o paliativni oskrbi, ki ga izvajajo v 18 državah, in sicer podajajo predvsem evalvacijo programov Zadnja pomoč v Sloveniji. Pomembno vlogo v vzgoji in izobraževanju za zdravje imajo tudi zdravstveni delavci. Lipovec Čebron in Huber sta v članku Evalvacija kulturnih kompetenc na področju zdravstva: Zakaj je potrebno vpeljati kvalitativne pristope? predstavili različne poskuse merjenja kulturnih kompetenc v zdravstvu. Na podlagi primerov iz tujine in Slovenije sta dokazovali, kako pomembno je na tem področju dopolnjevanje kvantitativnih metod s kvalitativnimi ter kako potrebno je premakniti pozornost od merjenja kulturnih kompetenc posameznih zdravstvenih delavcev k evalvaciji celotnega izobraževanja in njegovih izvajalcev.

\section{Uršula Lipovec Čebron in Nives Ličen}

\section{LITERATURA IN VIRI}

Cardano, M., Giarelli, G. in Vicarelli, G. (ur.). (2020). Sociologia della salute e della medicina. Il Mulino.

English, L. (ur.). (2012). Adult education and health. University of Toronto. https://doi. org/10.3138/9781442685208

Francescato, D., Tomai, M. in Ghirelli, G. (2020). Fondamenti di psicologia di comunità. Carocci.

Gilbert, G., Sawyer, R. in McNeill, E. (2015). Health education: Creating strategies for school and community health. Jones \& Bartlett Learning.

Lauzon, A. in Farabakhsh, R. (2014). The power of collaborative inquiry and metaphor in meeting the health literacy needs of rural immigrant women: A case of parent education. V V. Wang (ur.), Handbook of research on adult and community health education: Tools, trends, and methodologies (str. 51-67). IGI Global. https://doi.org/10.4018/978-1-4666-6260-5.ch004

Leahy, D., Fitzpatrick, K. in Wright, J. (ur.). (2020). Social theory and health education: Forging new insights in research. Routledge. https://doi.org/10.4324/9781351048163

Nutbeam, D. (2019). Health education and health promotion revisited. Health Education Journal, 78(6), 705-709. https://doi.org/10.1177/0017896918770215

Nutbeam, D., Levin-Zamir, D. in Rowlands, G. (ur.). (2019). Health literacy in context: Settings, media, and populations. MDPI. https://doi.org/10.3390/books978-3-03897-472-7

Pokorn, N. in Lipovec Čebron, U. (ur.). (2019). Večjezično zdravje: Komunikacijske strategije in večkulturni stiki s tujejezičnimi bolniki v slovenskem zdravstvenem sistemu. Znanstvena založba Filozofske fakultete Univerze v Ljubljani. https://doi.org/10.4312/9789610601364

Seedat, M., Suffla, S. in Christie, D. (ur.). (2017). Emancipatory and participatory methodologies in peace, critical, and community psychology. Springer. https://doi.org/10.1007/978-3-319-63489-0

Silberberg, M., Muhlbaier, L., Hart-Brothers, E., Weaver, S. in James, S. (2020). The role of socioeconomic status in a community-based study of diabetes secondary prevention among African 
Americans. International Journal of Health Promotion and Education. https://doi.org/10.1080/14 635240.2020 .1866999

Wang, V. (ur.). (2014). Handbook of research on adult and community health education: Tools, trends, and methodologies. IGI Global. https://doi.org/10.4018/978-1-4666-6260-5

Willis, C. D., Saul, J. E., Bitz, J., Pompu, K. in Jackson, B. (2014). Improving organizational capacity to adress health literacy in public health: A rapid realist review. Public Health, 128(6), 515-524. https:// doi.org/10.1016/j.puhe.2014.01.014 